\title{
PENGARUH MODEL GROUP INVESTIGATION (GI) TERHADAP KETERAMPILAN PROSES SAINS SISWA SMA PADA MATERI SISTEM EKSKRESI MANUSIA
}

\author{
Rehulina Barus ${ }^{1}$, Aida Fitriani Sitompul ${ }^{2}$ \\ 1.2 Jurusan Biologi FMIPA Universitas Negeri Medan \\ e-mail : rehulinabarus@gmail.com; aidasitompul@unimed.ac.id
}

\begin{abstract}
ABSTRAK
Penelitian ini bertujuan untuk mengetahui model pemeblajaran group investigation (GI) terhadap keterampilan proses sains siswa kelas XI MIA di SMA Negeri 5 Medan pada tahun pembelajaran 2015/2016 pada praktikum system eksresi pada manusia. Penelitian ini merupakan penelitian eksperimen, dengan penyajian data deskriptif. Sampel yang digunakan adalah kelas XI MIA ${ }_{5}$ sebagai kelas eksperimen dan XI MIA ${ }_{6}$ sebagai kelas control. Pengambilan sampel menggunakan tehnik random sampling. Variabel bebas dalam penelitian ini yaitu model pembelajaran Group Investigation (GI) sedangkan variabel terikatnya adalah keterampilan proses sains siswa. keterampilan proses sains siswa di lihat dari 9 keterampilan, yaitu keterampilan membuat pertanyaan, keterampilan merumuskan hipotesis, keterampilan merencanakan percobaan, keterampilan menggunakan alat dan bahan, keterampilan melakuakan observasi, keterampilan menginterpretasikan data pengamatan, keterampilan mengklasifikasikan hasil pembahasan, keterampilan menerapkan konsep dan keterampilan mengkomunikasikan. Berdasarkan hasil observasi menggunakan rubrik penilaian diperoleh skor keterampilan proses sains siswa yang diajar dengan menggunakan model Group Investigation (GI) lebih tinggi dibandingkan dengan siswa yang diajar dengan menggunakan pembelajaran langsung $(84,33>67,52)$. Berdasarkan hasil tersebut dapat disimpulkan bahwa model pembelajaran Group Investigation (GI) berpengaruh terhadap keterampilan proses sains siswa.
\end{abstract}

Kata kunci : Group Investigation, Keterampilan Proses Sains, Sistem eksresi

\section{ABSTRACT}

This study aims to determine the model of group investigation (GI) learning skills of science students in the class XI MIA in SMA Negeri 5 Medan in the year 2015/2016 learning on practicum excretion system in humans. This research is an experimental research, with presentation of descriptive data. The sample used is class XI MIA 5 as experiment class and XI MIA 6 as control class. Sampling using random sampling technique. The independent variable in this research is Group Investigation (GI) model study whereas the dependent variable is students' science process skill. students' science process skills in view of the 9 skills, ie question-making skills, hypothesis formulating skills, experimental planning skills, skills using tools and materials, observational skill, skills of interpreting observational data, classifying skills, discussion skills, and communicating skills. Based on the observation result using the scoring rubric, the score of students science process skill which was taught using Group Investigation (GI) model was higher than the students taught by using direct learning $(84,33>67,52)$. Based on these results, it can be concluded that the Group Investigation (GI) model influences the students' science process skills.

Keywords: Group Investigation, Science Process Skills, Excretion System

\section{PENDAHULUAN}

Pada hakikatnya pembelajaran sains khususnya biologi merupakan pembelajaran yang berorientasi kehidupan yang pelaksanaannya sangat dipengaruhi oleh lingkungan masyarakat. Karakteristik materi biologi adalah berupa fakta, konsep, prinsip, dan proses dari gejala-gejala hidup, serta seluk beluk yang mempengaruhi hidup termasuk interaksinya dengan lingkungan (Hasruddin, 2009). Siswa yang belajar sains tidak lagi menerima informasi tentang produk sains, tetapi melakukan proses ilmiah untuk menemukan fakta dan membangun konsep dan prinsip di bidang biologi. Sehingga dalam pembelajarannya guru harus menekankan pada pemberian pengalaman belajar secara langsung agar 
siswa mampu mengembangkan proses berfikir ilmiahnya dan menerapkan teori biologi yang telah dipelajari ke dalam kehidupannya.

Sains adalah ilmu pengetahuan yang mempelajari gejala-gejala melalui serangkaian proses yang dikenal dengan proses ilmiah yang dibangun atas dasar sikap ilmiah dan hasilnya terwujud sebagai produk ilmiah yang tersusun atas tiga komponen terpenting berupa konsep, prinsip, dan teori yang berlaku secara universal (Trianto, 2012). Keterampilan proses sains merupakan media untuk mengembangkan keterampilan berpikir ilmiah seperti keterampilan menganalisis, berpikir kreatif, proses sains dan logis, serta memecahkan masalah (Hanisa, 2012). Penerapan keterampilan proses dalam pembelajaran biologi dapat diintegrasi di dalam kegiatan praktikum siswa.

Penelitian yang dilakukan mengatakan bahwa kegiatan praktikum atau percobaan sains yang diselenggarakan sekolah menengah merupakan kegiatan praktikum yang cenderung mendorong siswa untuk tidak jujur, karena hasil pengamatannya dikendalikan oleh teori/prinsip/konsep yang sudah diketahuinya.

Menurut Rusman (2014) pembelajaran kooperatif merupakan salah satu model pembelajaran yang sangat berguna untuk menumbuhkan kemampuan kerjasama, berfikir ilmiah dan kemampuan membantu teman sehingga diharapkan akan berdampak pada peningkatan keterampilan proses sains siswa.

Model pembelajaran kooperatif tipe group investigation (GI) merupakan salah satu bentuk model pembelajaran kooperatif yang menekankan pada partisipasi dan aktivitas siswa untuk mencari sendiri materi (informasi) pelajaran yang akan dipelajari melalui bahan-bahan yang tersedia, misalnya dari buku pelajaran. Tipe ini menuntut para siswa untuk memiliki kemampuan yang baik dalam berkomunikasi maupun dalam keterampilan proses kelompok (Abas, 2012).

Menurut Slavin pembelajaran kooperatif tipe GI sangatlah ideal diterapkan dalam pembelajaran biologi (IPA). Dengan topik materi IPA yang cukup luas dan desain tugas-tugas dan sub-sub topik yang mengarah kepada kegiatan metode ilmiah, diharapkan siswa dalam kelompoknya dapat saling memberi kontribusi berdasarkan pengalaman sehariharinya. Oleh karena itu model pembelajaran kooperatif tipe GI ini sangat cocok digunakan pada praktikum sistem ekskresi manusia yang menuntut adanya kegiatan investigasi (penyelidikan). Berdasarkan uraian di atas, maka perlu dilakukan penelitian untuk mengetahui pengaruh model pembelajaran Group Investigation (GI) terhadap keterampilan proses sains siswa SMA pada materi sistem ekskresi manusia.

\section{METODE PENELITIAN}

Jenis penelitian yang digunakan dalam penelitan ini adalah penelitian eksperimen, namun data penelitian di sajikan secara deskriptif. Satu kelas dijadikan kelas eksperimen yang dibelajarkan dengan model pembelajaran group investigation (GI) untuk melihat adanya pengaruh model pembelajaran group investigation (GI) terhadap 9 keterampilan proses sains, yaitu keterampilan membuat pertanyaan, keterampilan berhipotesis, keterampilan merencanakan percobaan, keterampilan menggunakan alat dan bahan, keterampilan mengobservasi, keterampilan menafsirkan/menginterpretasikan data, keterampilan mengklasifikasikan/mengelompokkan, keterampilan menerapkan konsep, dan keterampilan mengkomunikasikan dan kelas lainnya dijadikan kelas kontrol yang dibelajarkan dengan model pembelajaran langsung sebagai pembanding skor keterampilan proses sains siswa.

Penelitian ini dilaksanakan di SMA Negeri 5 Medan, beralamat di Jalan Pelajar No. 17 Medan, pada bulan Januari sampai Juni 2016.

Populasi dalam penelitian ini adalah seluruh siswa kelas XI MIA SMA Negeri 5 Medan Tahun Pembelajaran 2015/2016 yang terdiri dari 10 kelas dengan jumlah siswa sebanyak 378 orang.

Sampel pada penelitian sebanyak dua kelas yaitu kelas XI MIA ${ }_{5}$ dengan jumlah siswa sebanyak 35 orang dan $\mathrm{XI} \mathrm{MIA}_{6}$ dengan jumlah siswa sebanyak 29 orang. Pengambilan sampel menggunakan teknik random sampling, yaitu pengambilan sampel secara acak.

\section{Instrumen Pengumpulan Data}

Instrumen yang digunakan dalam pengumpulan data adalah instrumen penilaian kinerja dalam bentuk rubrik penilaian. Instrumen penilaian kinerja merupakan penilaian yang dilakukan dengan mengamati kegiatan peserta didik dalam melakukan kegiatan pembelajaran. Penilaian ini cocok digunakan untuk menilai ketercapaian kompetensi yang menuntut peserta didik melakukan tugas tertentu seperti praktek di laboratorium. Cara 
penilaian ini dianggap lebih autentik daripada tes tertulis karena apa yang dinilai lebih mencerminkan kemampuan peserta didik yang sebenarnya.

\section{Teknik Analisis Data}

Data yang diperoleh dari hasil observasi adalah data kuantitatif kemudian diklasifikasikan menjadi dua kelompok data, yaitu data keterampilan proses sains siswa dalam kelompok belajar dan data keterampilan proses sains siswa secara individu. Teknik analisis data dalam penelitian ini dilakukan secara deskriptif dengan bantuan Microsoft Excel.

Perhitungan persentase aktivitas keterampilan proses sains siswa pada kegiatan

\section{HASIL DAN PEMBAHASAN}

Penelitian ini dilakukan untuk mengetahui adanya pengaruh model pembelajaran group investigation (GI) terhadap keterampilan proses sains siswa. Keterampilan proses sains ini dilihat dari 9 keterampilan, yaitu keterampilan membuat pertanyaan, keterampilan merumuskan hipotesis, keterampilan merencanakan percobaan, praktikum selama pembelajaran dihitung dengan menggunakan rumus :

$$
N=\frac{\text { Skor diperoleh }}{\text { Skor total }} \times 100 \%
$$

Keterangan :

$\mathrm{N}=$ Nilai

Keterangan kriteria interpretasi skor :

$$
\begin{aligned}
& 0 \%-30 \%=\text { Rendah } \\
& 31 \%-60 \%=\text { Sedang } \\
& 61 \%-100 \%=\text { Tinggi }
\end{aligned}
$$

keterampilan menggunakan alat dan bahan, keterampilan melakuakan observasi, keterampilan menginterpretasikan data pengamatan, keterampilan mengklasifikasikan hasil pembahasan, keterampilan menerapkan konsep dan keterampilan mengkomunikasikan.

\section{Keterampilan Proses Sains Siswa dalam Kelompok}

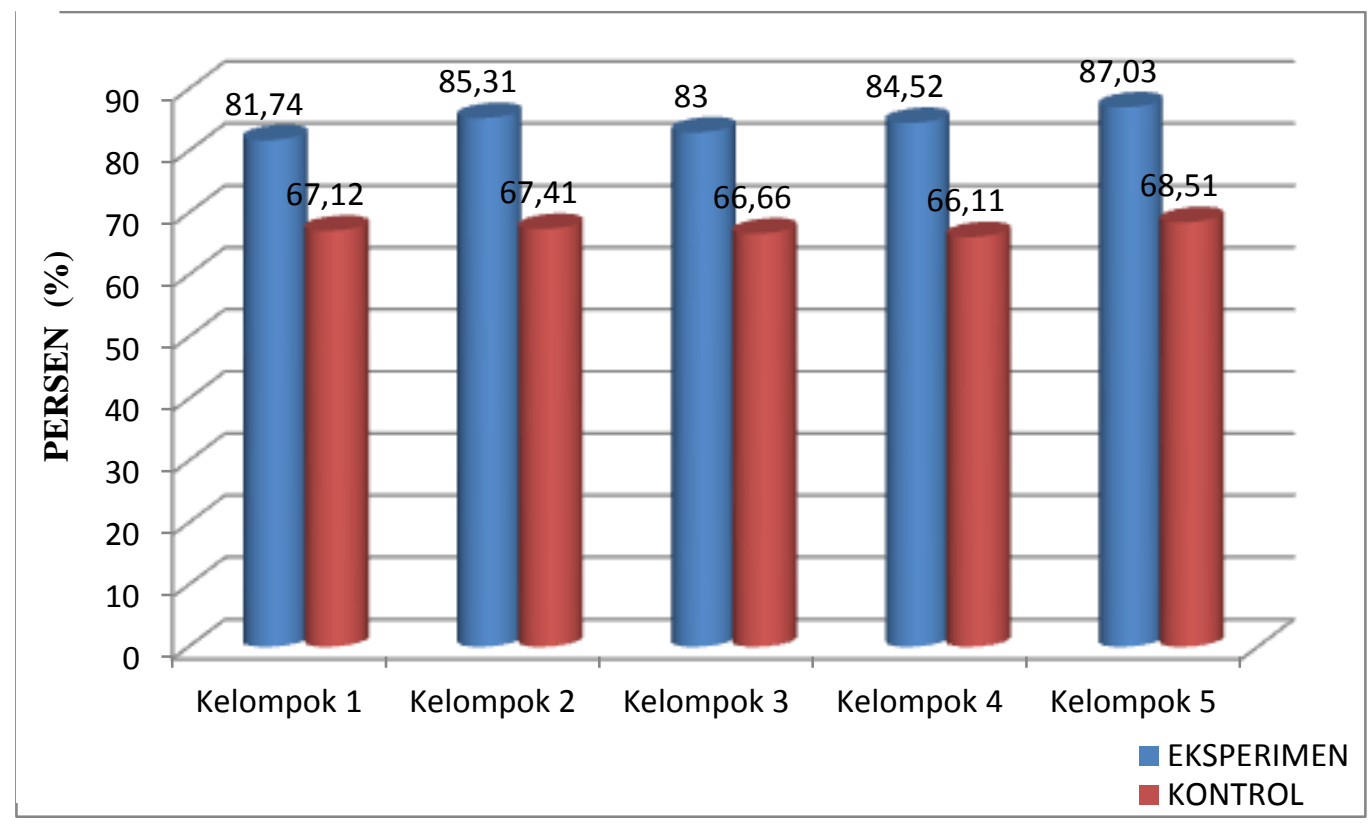

Gambar 1. Perbandingan Keterampilan Proses Sains Siswa dalam Kelompok

Berdasarkan diagram diatas terlihat adanya perbedaan antara nilai keterampilan proses sains siswa yang diajar dengan model pembelajaran group investigation (GI) dengan nilai keterampilan proses sains siswa yang diajar dengan model pembelajaran langsung. Dimana terlihat bahwa siswa yang diajar dengan model pembelajaran GI memiliki nilai yang lebih tinggi dibandingkan dengan siswa yang diajar dengan model pembelajaran langsung. Perbedaan tersebut mencapai $\pm 25 \%$.

Adanya perbedaan tersebut membuktikan bahwa model pembelajaran group investigation berpengaruh terhadap keterampilan proses sains kelompok siswa, karena sintaks dalam model 
pembelajaran GI sangat sesuai dengan pebelajaran praktikum yang berdasarkan terhadap penyelidikan di dalam kelompok belajar. Sehingga siswa dapat mengembangkan kemampuan berfikir ilmiahnya dengan melakukan diskusi dengan teman kelompoknya dan dapat meningkatkan kemampuan keterampilan proses sainsnya. Berbeda dengan pembelajaran menggunakan model pembelajaran langsung yang hanya membuat siswa untuk belajar didalam kelompok belajar tanpa benar-benar melakukan penyelidikan (investigasi) dalam kelompok belajar. Sehingga model pembelajaran langsung tidak berpengaruh terhadap keterampilan proses sains kelompok siswa.

Keterampilan Proses Sains Siswa Secara Individu

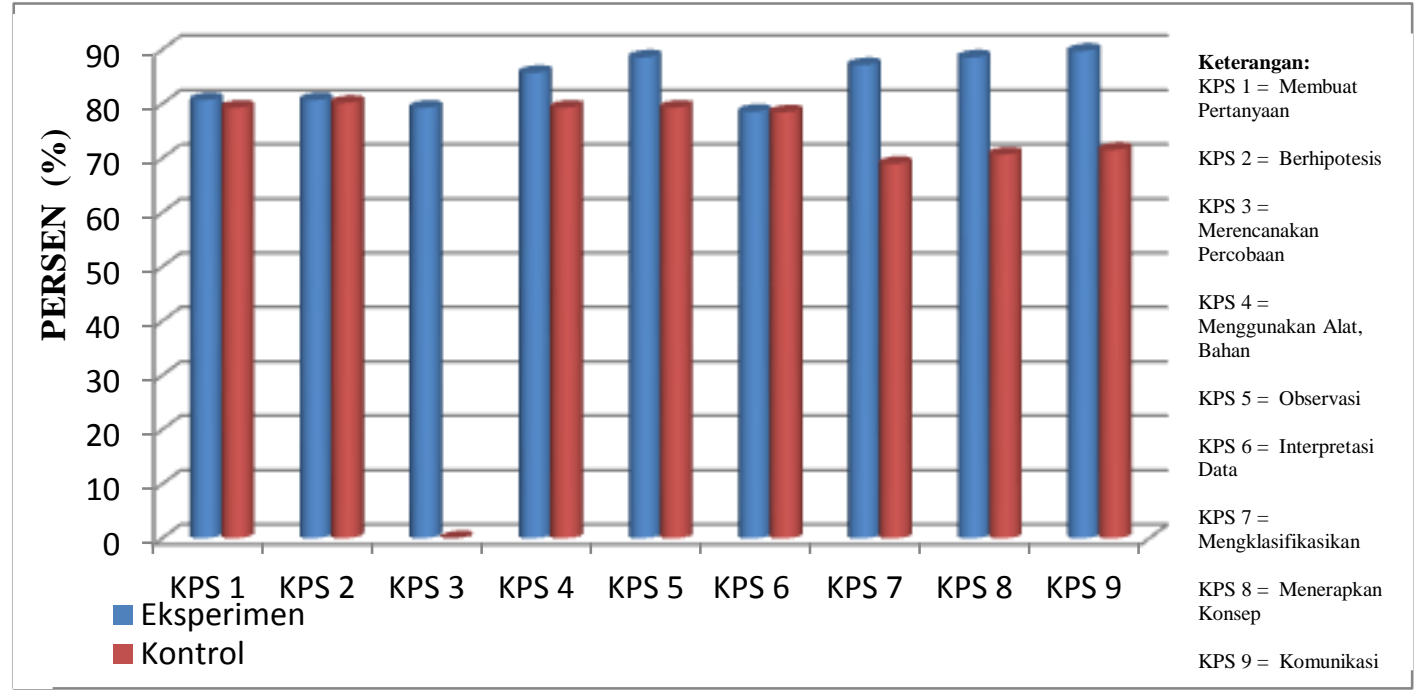

Gambar 2. Perbandingan Nilai Keterampilan Proses Sains Siswa Secara Individu

Keterampilan proses sains siswa pada indikator membuat pertanyaan mencapai rata-rata skor 80,71 pada kelas eksperimen yang dibelajarkan dengan model pembelajaran GI dan mencapai skor 79,31 pada kelas kontrol yang dibelajarkan dengan model pembelajaran langsung menunjukkan bahwa hampir keseluruhan siswa sudah kompeten dalam membuat pertanyaan atau merumuskan pertanyaan berdasarkan topik praktikum yang merika miliki baik pada kelas eksperimen maupun pada kelas kontrol. Namun terlihat ada sedikit perbedaan skor keterampilan proses sains pada kedua kelas tersebut, dimana pada kelas eksperimen memiliki skor yang lebih tinggi dibandingkan dengan kelas kontrol. Perbedaan tersebut dikarenakan pada kelas eksperimen sebelum melakukan kegiatan praktikum siswa diminta untuk memilih sendiri topik praktikum yang akan dilakukannya sesuai dengan minat yang mereka miliki, sehingga siswa tidak merasa kesulitan saat diminta untuk merumuskan pertanyaan, karena siswa memang meminati dan menyukai topik tersebut.
Data Nilai Keterampilan Proses Sains Siswa Secara Individu pada Model Group Investigation (GI) di Kelas Eksperimen

Persentase skor keterampian proses sains siswa tertinggi adalah skor keterampilan berkomunikasi, yaitu sebesar 89,75\% (Gambar 3). $\mathrm{Hal}$ ini dikarenakan dengan pembelajaran menggunakan model Gl siswa akan mengorganisasikan pembagian tugas kepada setiap anggota didalam kelompoknya sehingga pada saat presentasi siswa akan menjelaskan dan mengkomunikasikan hasil pengamatan mereka berdasarkan pembagian tugas yang sudah mereka lakukan sebelumnya. Sehingga materi dan hasil pengamatan dapat dikomunikasikan dengan baik. Dan skor terendah adalah pada keterampilan menginterpretasikan data, hal ini dikarenakan siswa belum terbiasa untuk menyajikan data dengan interpretasi yang bervariasi untuk dapat lebih mudah dipahami, siswa hanya menyajikan data dengan tabel sederhana. 


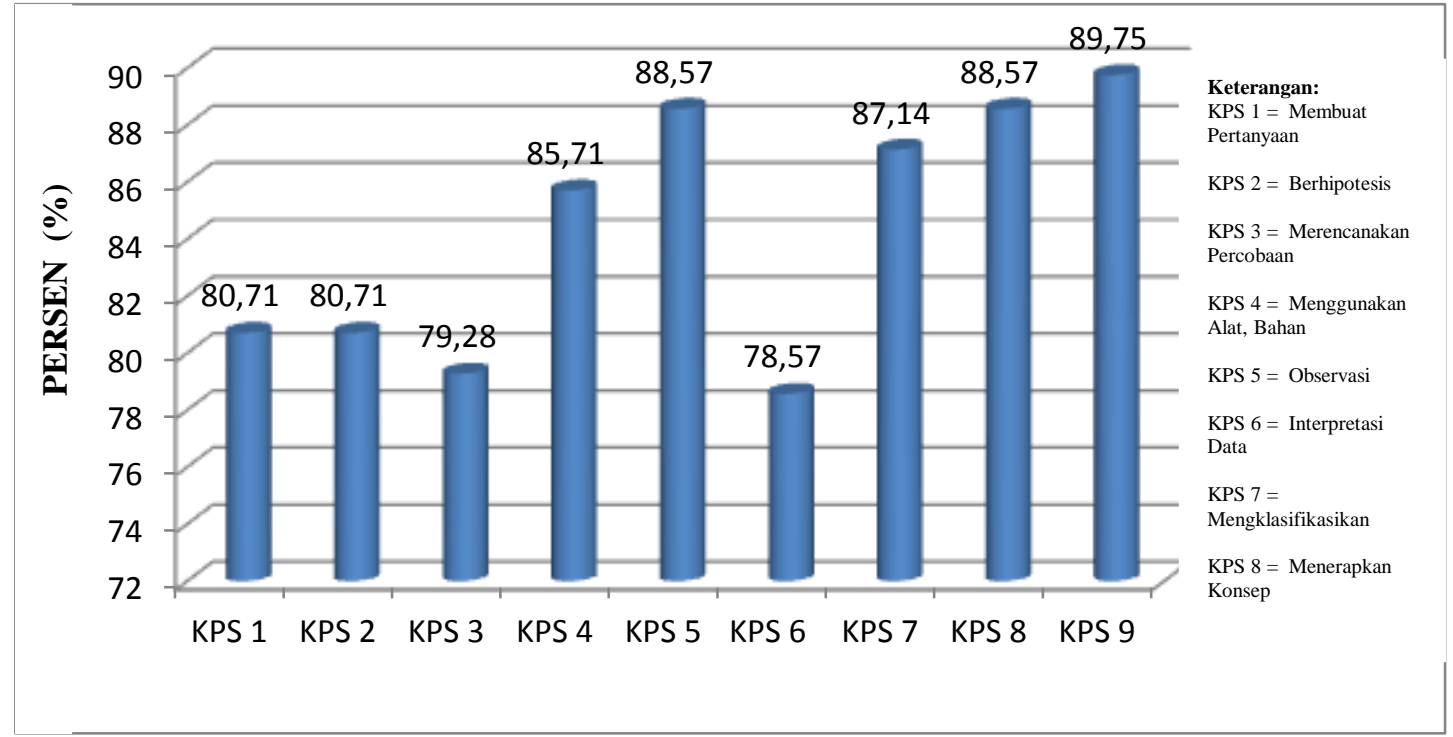

\section{Gambar 3. Diagram Skor Keterampilan Proses Sains Siswa Secara Individu pada Model Group Investigation}

Data Nilai Keterampilan Proses Sains Siswa Secara Individu pada Model Pembelajaran Langsung di Kelas Kontrol

Berdasarkan diagram di bawah ini dapat diketahui bahwa perbedaan skor dari 9 keterampilan proses sains tidak jauh berbeda, kecuali pada KPS 3, yaitu keterampilan membuat rencana percobaan yang skor keterampilan proses sainsnya adalah $0 \%$. Hal ini dikarenakan dengan menggunakan model pembelajaran langsung siswa tidak dimotivasi untuk melakukan penyelidikan ilmiah untuk mengembangkan dan melatih kemampuan berfikir ilmiah.

Keterampilan membuat rencana percobaan dengan membuat prosedur kerja praktikum tidak dapat dilkukan dengan menggunakan model pembelajaran langsung, karena model pembelajaran langsung sudah menyediakan prosedur kerja praktikum yang rinci dan baku.skor keterampilan proses sains siswa tidak jauh berbeda antara keterampilan proses sains.

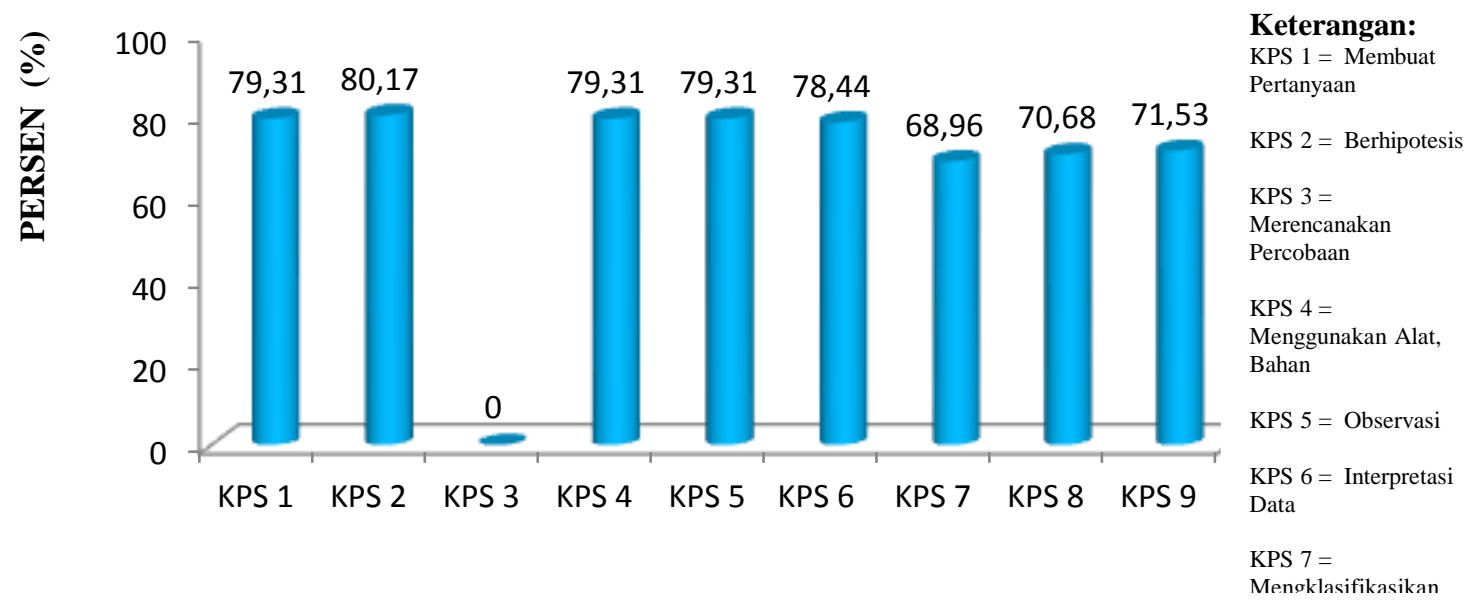

Gambar 4. Diagram Nilai Keterampilan Proses Sains Siswa Secara Individu pada Model Pembelajaran Langsung 
JURNAL PELITA PENDIDIKAN VOL. 5 NO. 2

Barus, Rehulina \& Sitompul, A.F.

Halaman : $031-038$

Keterampilan proses sains siswa pada indikator merencanakan percobaan dilihat dari kemampuan siswa untuk merancang sendiri prosedur praktikum atau percobaannya sesuai dengan topik yang mereka miliiki. Pada kelas eksperimen keterampilan merencanakan percobaan mencapai rata-rata skor 79,28 dan mencapai skor 0 (nol) pada kelas kontrol. Hal ini menunjukkan bahwa siswa pada kelas eksperimen sudah mampu untuk melakukan keterampilan merencanakan percobaan dengan baik. Namun pada kelas kontrol keterampilan ini tidak dapat dilakukan karena dengan menggunakan model pembelajran langsung sudah tersedia prosedur praktikum yang rinci dan baku yang akan dipakai siswa untuk melakukan percobaan sesuai topik praktikum yang mereka miliki. Hal ini menunjukkan bahwa pembelajaran dengan menggunakan model pembelajaran GI sangat baik untuk melatih keterampilan siswa dalam merencanakan percbaan. Selain itu kemampuan berfikir ilmiah siswa juga akan dilatih sehingga siswa akan terbiasa untuk berfikir secara ilmiah dalam melakukan pengamatan.

Model pembelajaran group investigation memang memiliki kelebihan dalam hal kerja sama kelompok untuk penguasaan materi. Dalam model ini, siswa dituntut untuk dapat mengembangkan daya nalarnya dalam melakukan investigasi untuk menguasai kemampuan akademik dalam pengertian penguasaan materi pembelajaran, tetapi juga ada unsur kerja sama untuk penguasaan materi tersebut. Model ini melatih siswa mengembangkan kemampuan berpikir siswa. Untuk itu maka sangat tepat menggunakan model ini sebagai latihan bagi siswa dalam meningkatkan keterampilan proses sains.

Keahlian-keahlian yang turut juga dibentuk selama proses pembelajaran ini yaitu kolaborasi yang dikembangkan bersama dengan guru pembimbing, komunikasi yang dikembangkan antar dan intra kelompok. Hasil kerja siswa yang kemudian dipresentasikan oleh masing-masing kelompok di depan kelompok lain juga turut mengembangkan kemampuan komunikasi siswa.

Model pembelajaran group invesrigasi merupakan model yang tepat untuk melatih siswa mengembangkan keterampilan berpikirnya dengan kegiatan investigasi dalam kelompok belajar. Siswa didorong untuk melakukan aktivitas yang dapat mengeksplor pengalaman dan ide-ide yang dimiliki
pISSN : 2338 - 3003

elSSN : $2502-3217$ siswa. Kegiatan-kegiatan penyelidikan dan pemecahan masalah yang merupakan bagian dari model ini akan membentuk siswa yang pemikir dan independen.

\section{SIMPULAN}

Berdasarkan hasil penelitian yang telah dikemukakan pada bab sebelumnya bahwa pada kelas eksperimen dengan menggunakan model GI skor keterampilan proses sains tertinggi adalah keterampilan mengkomunikasikan yaitu 89,75 dan skor terendahnya adalah keterampilan interpretasi data yaitu 78,57 sedangkan pada kelas kontrol dengan menggunakan model pembelajaran langsung skor keterampilan proses sains yang tertinggi adalah keterampilan mengajukan hipotesis yaitu 80,17 dan keterampilan terendah adalah keterampilan mengklasifikasikan yaitu 68,96. Skor rata-rata keterampilan proses sains siswa juga menunjukkan bahwa siswa yang diajar dengan menggunakan model pembelajaran group investigation lebih tinggi dibandingkan dengan siswa yang diajar dengan mengguanakan model pembelajaran langsung $(84,33$ $>$ 67,52), terdapat perbedaan sebanyak 19,93\%. Maka dapat disimpulkan bahwa Penerapan model pembelajaran group investigation memberikan pengaruh terhadap keterampilan proses sains siswa kelas XI MIA SMA Negeri 5 Medan pada praktikum sistem ekskresi manusia. Hal ini ditunjukkan dari skor keterampilan proses sains individu maupun kelompok siswa dan skor rata-rata pada kelas eksperimen lebih unggul dibanding kelas kontrol.

\section{DAFTAR PUSTAKA}

Abas, (2012), Perbandingan Hasil Belajar Model Cooperative Learning Dengan Model Science Technology Society Pada Siswa Kelas X MAN 1 Model Kota Bengkulu, Jurnal Exacta, 1 (10): 11 - 16.

Hasruddin, (2009), Peran Multi Media Dalam Pembelajaran Biologi, Jurnal Tabularasa PPS Unimed, 2 (6): 149 - 160.

Ibnu, T., (2014), Mendesin Model Pembelajaran Inovatif, Progresif, dan Kontekstual, Prenadamedia Group: Jakarta.

Maknun, D., Hertien R., Ahmad M., (2012), Praktikum Ekologi berbasis Proyek: Media Pembekalan Keterampilan Esensial 
Laboratorium, Jurnal Pendidikan MIPA, 1 (13): $8-17$.

Pratiwi, D.A., (2007), Buku Penuntun Biologi SMA untuk Kelas XI Jilid 2, Erlangga, Jakarta.

Rosiani, L., (2011), Pengaruh Pendekatan Keterampilan Proses Sains Terhadap Hasil Belajar Biologi Siswa (Kuas Eksperimen di SMA Negeri 4 Kota Tangerang Selatan), Skripsi, UIN Syarif Hidayatullah, Jakarta.

Rusman, (2014), Model - model Pembelajaran:Mengembangkan

Profesionalisme Guru Edisi ke II, PT Raja Grafindo Persada: Jakarta.

Rustaman, N., (2007), Belajar IPA Melalui Keterampilan Proses Sains, http://file.upi.edu/Direktori/SPS/PRODI .PENDIDIKAN IPA/195012311979032NURYANI RUSTAMAN/KPS vs KG.pdf (Diakses pada 25 Februari 2016).

Saleh, M., (2012), Pembelajaran Kooperatif Dengan Pendekatan Pendidikan Matematika Realistic (PMR), Jurnal Pendidikan Serambi Ilmu, 2 (13): 51 - 59.

Suyanto, (2015), Meningkatkan Prestasi Belajar IImu Pengetahuan Sosial Melalui Pembelajaran Kooperatif Model Group Investigation (GI) Pada Siswa Kelas VI SDN Lamongrejo I Kecamatan Ngimbang Kabupaten Lamongan Tahun Pelajaran 2009/2010, Jurnal Media Edukasi, 2 (1) : $10-16$. 